\title{
PHOTOJOURNALISM AND PRESS PHOTOGRAPHY AS A REASSURANCE OF REALITY
}

\author{
Assist. Prof. Qasem Abdel-Karim SHUKRAN *
}

\begin{abstract}
Press photographs meet us as individual images or in bigger groups in the context of a report or sequence, in publish or online media, published as print negatives, slides or digital files. The mass of published images follows positive image patterns or photo types that are constantly repeated and handed down a culture of set recognition. So, these images not only submit to other photographs but also often to subjects from other visual media, such as, for example, the painting. Although the drawing of boundaries between art and press photography becomes increasingly porous and the mutual reference of these genres is widely used, it is still worth asking what specifically characterizes a press photo. First of all, press images are photographs originated at a specific location that want to make a statement about this place and a specific action. A certain representationally or likeness is common to them, so that they seem to reflect reality with special truthfulness. In this sense, press images are used in their respective publication contexts as information carriers, which have a particular function of testifying or proving. Similar to the history painting in the 19th century, press images must visualize a complex situation comprehensibly and catchy. In order to guarantee and to support their readability, almost all press images have an accompanying text or a caption.
\end{abstract}

Keywords: Photojournalism, Press Photography, Reality, Recognition, Representation.

* Yarmouk University, Faculty of Fine Arts, Visual Arts Department, Irbid /JORDAN, shukran@yu.edu.jo 


\title{
GERÇEKLiĞin BIR GÜVENCESI OLARAK FOTOĞRAF GAZETE- CILLĞi VE BASIN FOTOĞRAFÇILIĞI
}

\author{
Yrd. Doç. Qasem Abdel-Karim SHUKRAN*
}

\section{ÖZET}

Basın fotoğrafları, bir rapor ya da dizi bağlamında büyük gruplar ya da tek tek görüntüler halinde, basıl y y da çevrimiçi medyada, negatiflerden baskılar, slaytlar ya da sayısal dosyalar halinde yayınlanmış olarak karşımıza çıkmaktadır. Basılı görüntüler topluluğu, sürekli tekrarlanan ve set tanıma kültürü olarak miras kalan pozitif görüntü örnekleri ya da fotoğraf türlerini takip eder. Bu yüzden bu görüntüler, sadece diğer fotoğraflara ait olmayıp, aynı zamanda genellikle resim gibi diğer görsel medyadan konulara da ait olabilir. Gerçi sanat ve basın fotografçıllğı arasında sınır çizmek, artan şekilde geçirgen ve janrların ortak referansları oldukça kullanılır hale getirmiştir, bir basın fotografını neyin özellikle karakterize ettiğini halen sorgulamaya değerdir. Her şeyin ötesinde, basın görüntüleri, bu yerde ve belli bir etki hakkında yapılması istenen, belirlenmiş bir konumda kaynaklanan fotograflardır. Kesin bir gösterimsel veya beğenirlilik onarın ortak noktasıdır ki onlar, özel doğrulukla gerçeği yansıtır gibidirler. Bu anlamda, basın görüntüleri, deneme veya kanıtlamanın işlevine sahip bilgi taşıyıcılar olarak kendilerine has yayıncılık bağlamında kullanırlar. 19. yy.daki tarihi resime benzer şekilde, basın görüntüleri, kapsamlı ve dikkat çekici olan karmaşık bir olayı görselleştirmelilerdir. Algilanabilirliklerini garanti altına almak ve destek amacıla hemen hemen tüm basın görüntüleri onlara eşlik eden metin veya altyazı ihtiva ederler.

Anahtar Sözcükler: Fotoğraf gazeteciliği, Basın fotoğraçılı̆̆ı, Gerçeklik, Tanıma, Sunma

* Yarmouk Üniversitesi, Güzel Sanatlar Fakültesi, Plastik Sanatlar Bölümü, İrbid /ÜRDÜN,

shukran@yu.edu.jo 


\section{INTRODUCTION}

Photographs follow most definite strategic picture patterns that are culturally learned and immediately give us picture categories due to the iconographic tradition of representation, such as "crime scene photography" or "victim picture". In this relation, not only the iconographic image pattern is recognized, but also its significant imagery can immediately be implicit. The subjects and their significance are stored in the collective memory of the image and are recognized by the observer and thus updated. The ambiguity of images is reduced by a specific appeal achieved by the topic of tradition, so that they are more immediately understandable. In the perspective of the media, these images have greater chances of attention (Benjamin 1989).

\section{Research Problem}

In the classical sense, the term "press photography" refers to a single photograph usually printed in the newspaper or a magazine. Therefore, it must be distinguished from photojournalism, which presents multiple images, mostly image sequences in one context. In addition, press photographs are more characterized by a visual language that attempts to illustrate certain coherences with a single image.

In contrast to this, photojournalistic reportages are capable to visualize coherences by complex photo galleries. However, in the final analysis, a differentiation of press pictures and photojournalism can not be linked to intra-pictorial strategies, but it is primarily a result of the publication context, since it is naturally conceivable that a reportage photo is taken from a series and as a single image.

\section{Aims Of The Study}

- The study shows the notion of the documentary and its relationship to photography.

- The study explains the various concepts of the documentary and enters a representation of how journalistic press photographs work.

- The study shows the development and the rapid spread of documentary photography, not least by the many contexts of use, in which the photographs could find opportunities for publication.

- The study investigates press photography and its relationship with art history.

\section{Research Methodology}

tIn this study, I use the descriptive-analytical approach as a foundation for research. A descriptive survey attempts to picture or document concerning current conditions or attitudes, that is, to describe what exists at the moment. The analytical method is critical of solving the sustainability problem because it appears that current processes are inadequate. They are intuitive, simple, and based on how activists approach everyday problems.

2 http://www.moma.org/collection/object.php?object_id=79986 


\section{Making Of Photography}

A significant example of existing press photography on the cover topic of art history tradition is a well-known photograph shot by Flores on September 11, 2001. Firefighters raising the Flag at the WTC, Franklin shows the wreckage of the World Trade Center after the attack on September 11. Both the flag and the architectural remains of the tower project outline as two vertical elements from the destroyed building where the flag in the context of the photographs created by $9 / 11$ is a recurring theme and, in addition, the historical subject in Flores photography tags a strong ritual in the press photography. It views the destruction, so to speak. (Waskul, 2003) This effect is reinforced by Flores's image because it refers to the iconographic tradition of an image by Caspar David Friedrich. Friedrich's The Sea of Ice of 1823/24 corresponds to Flores 's picture concerning the subject of the fragmentary and shattering that is piling up in the middle, the view orientation, the dominance of the upward trending from the bottom right to a left slope, as well as the restrained color. Friedrich shows the impact of a ship disaster in the Arctic Ocean. Between the ice floes on the right, a ship lying on the side is looming. The scenery is just as deserted as in Flores 's photography. While the subject of the large, almost towering compilation of ice floes corresponds to the collapsed remains of a tower of the World Trade Center, Friedrich marks a vertical ice floe on the right part of the image, which is reflected as a graphic element in the flag picture of Flores. Caspar David Friedrich's painting of 1823/24 was frequently read as an allegory of glaciations and the climate change in Germany during the pre-March (German pronunciation: was a period in the history of Germany preceding the 1848 March Revolution in the states of theGerman Confederation) and "as an iconic expression of that cold that had fallen across the political landscape of Europe after the Congress of Vienna". (Okey, 2001) The painting can be implicit as an expression of resignation and hopelessness. This tradition was updated once again by Flores's photography of September 11 - besides the image of destruction, the subject of the flag already seems to refer to the future and is therefore an expression of hopelessness. In contrast, Flores's other pictures in the series focus on the destruction (visual 1 and visual 2) (Sullivan, 2012).

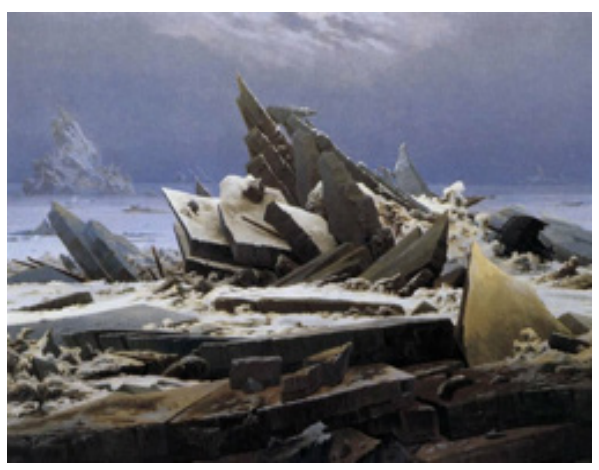

Visual 1. Caspar David Friedrich's painting of 1823/24 


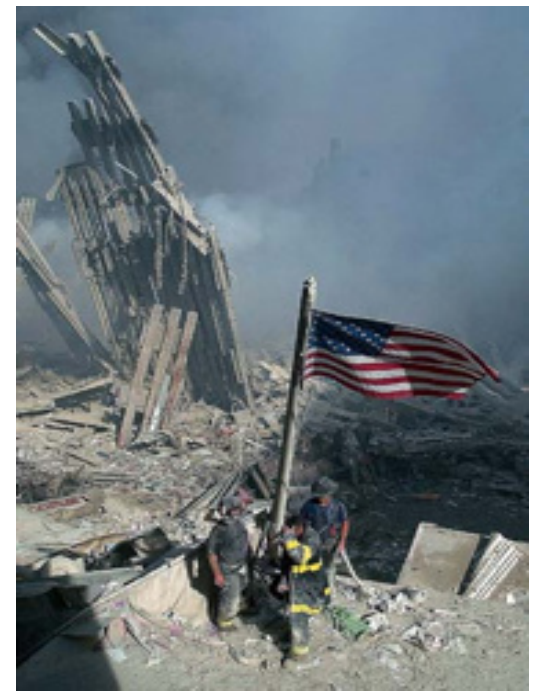

Visual 2. Firefighters raising the Flag at the WTC on September 11, 2001. Photo by Ricky Flores

\section{Photos Of Demonstration Reports}

A placement of images in the Context of iconographic quotes becomes particularly clear in the typology of demonstration photos. Principally mass media productions often cite the visual and affective importance of symbolic protests in media images. As a Mick Jagger's photograph from shows, Demonstrations - 1968 jan-jun Anti-vietnam War Protest March Carrying Their Banner Reading the Women Of Great Britain Plead For A Stop To The Slaughter In Vietnam (visual 3). We see a crowd run directly towards the camera apparently shouting slogans with a banner (Benjamin, 1989).

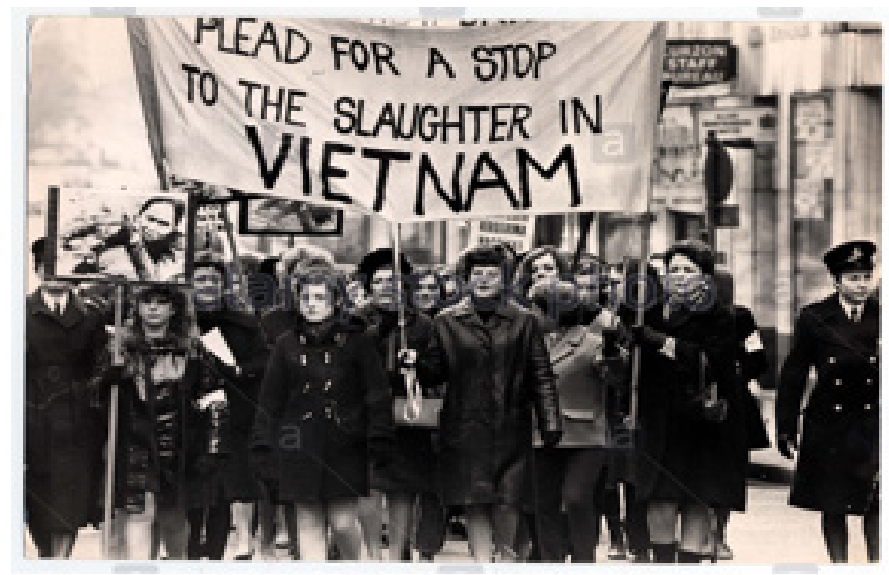

Visual 3. Anti-war: Mick Jagger took part in the demonstrations at Grosvenor Square, London in 1968 
The look into practically every news magazine or newspaper shows the abundance of photographs employing this recognizable iconography. A photograph of the young Magnum photographer Ben Curtis is a model that should be mentioned here. Curtis 's photo was shot on January 29, 2011 in Cairo during the protests against the regime of Hosni Mubarak (visual 4) (Giannetti, 2008).

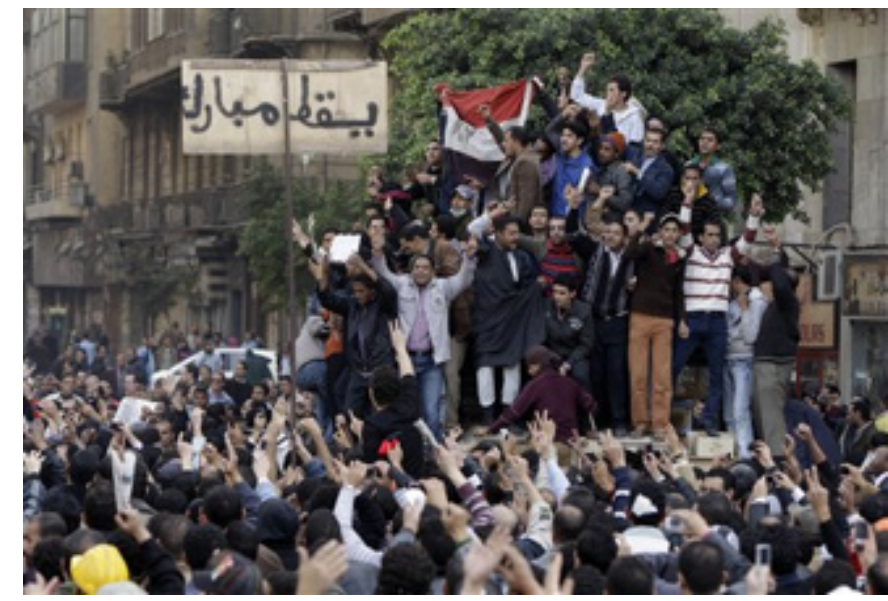

Visual 4. Egyptian anti-government protesters climb atop an Egyptian army armored personnel carrier, next to a signpost bearing the words "Down Mubarak", in Cairo, Egypt, Saturday, Jan. 29, 2011. (AP Photo/Ben Curtis).

This iconographic image pattern, acting as a symbol of protest and the abandoning of certain social standards, was even adopted by an advertising campaign for the company Diesel (visual 5). In KesselsKramer 's black and white photograph, you can see a group of young people moving directly towards the photographer in the spirit of classical iconography of symbolic protests shown by mass media productions. The proximity of the camera, the gestures of the young people, their mouths partly open, and the many falling and oblique lines emphasize the dynamics of the recording and show an apparently moving event. Thus, the viewer reads this as an expression of protest. This imperative is ultimately the close of campaign photography for press images in the context of political demonstrations, as it unhesitatingly takes over the gestures of these protest rallies, but calls a situation on a semantic level less placed in the context of political protest movements or questioning social norms than rather of their affirmation with the prompt to respect their planet (Sullivan, 2012). 


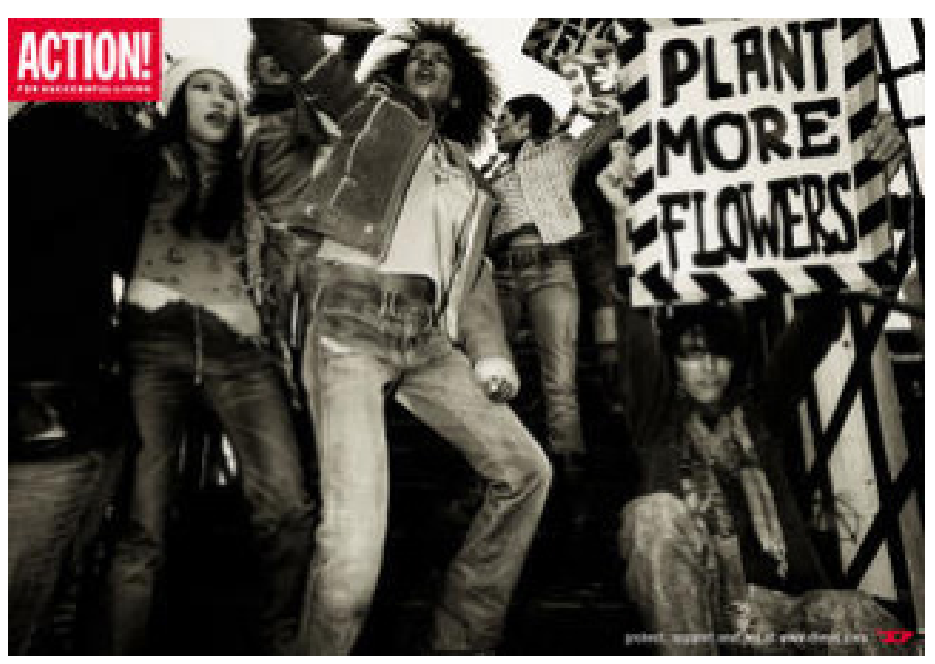

Visual 5. This first campaign is Action! for Diesel by KesselsKramer in Amsterdam. 2002

Originally considered as separate genres of photography, advertising photography takes over the image pattern of press photography here. Even the sobriety and objectivity evoked by the black and white, which dominated press photography for decades and thus is closely connected to the black of printing ink and the white of newsprint's paper, was adapted for the Diesel advertising, bearing in mind that the KesselsKramer is a representative of classic photojournalism and only occasionally realizes advertising jobs. Especially the slogan of the banners "Planet More Flowers" ironizes the semantic level of the protest conveyed by the image topos of the demonstration train (Alunno, 2013).

\section{The Picture Of The "Victims' Suffering" In The Press}

So. there are image patterns which already serve as signs or symbols by visualizing more abstract contexts such as the protest against social norms, the suffering of war victims, the hardship of the population, the joy of winners, etc. Since the subject of suffering is particularly present in press photography, I would like to illustrate the image-strategic conveying of the populations suffering with further examples. As a symbol of starvation, in particular to visualize the famines in many African countries, starving and pain children show very often. Starving children in Karamoja in northeastern Uganda during the famine of 1980. The famine followed drought and civil disorder and resulted in the deaths of a fifth of the population in the region. (Visual 6) (Białostocki, 2003). 


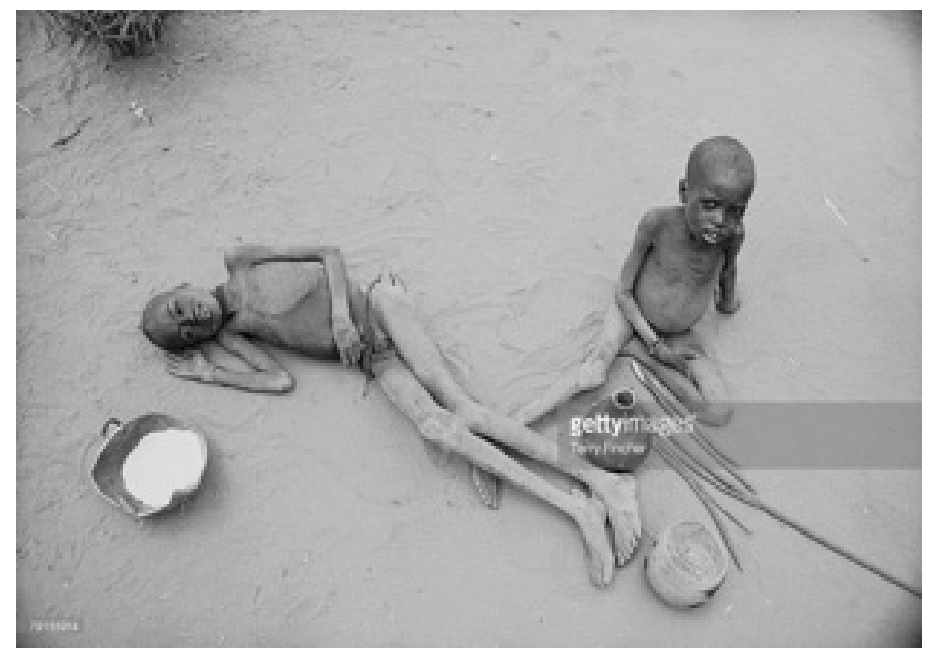

Visual 6. Terry Fincher. Starving children in Karamoja in northeastern Uganda during the famine of 1980. The famine followed drought and civil disorder and resulted in the deaths of a fifth of the population in the region.

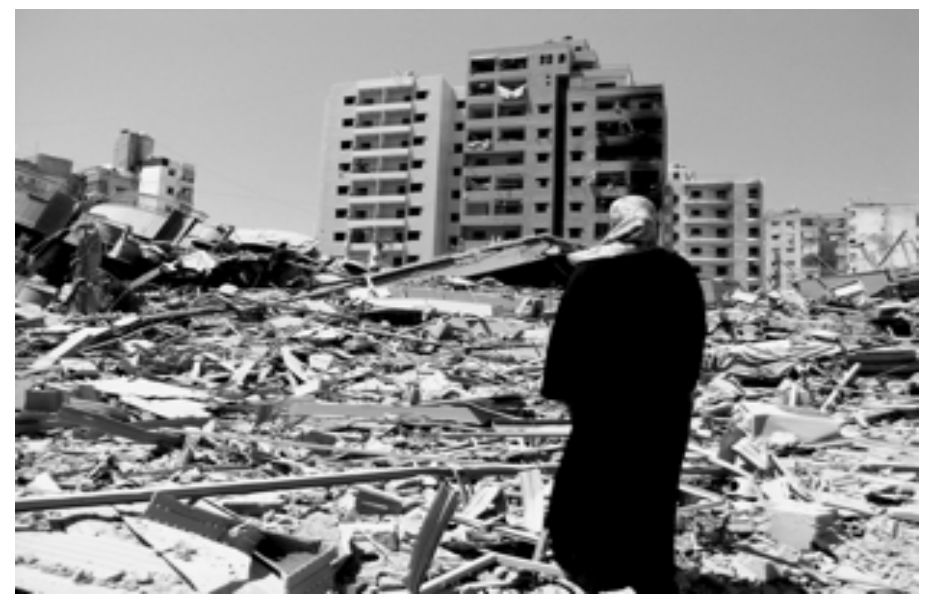

Visual 7. A woman looks at the destruction of Haret Hreyk after the ceasefire was declared on August 15th, 2006. (c)2006 Derek Henry Flood.

The occasion of the escalating conflict in Lebanon provides the suffering of the population through abstracting and symbolizing patterns (Visual 7). A woman is in the foreground, with dark clothing, and looking at the destruction of Haret Hreyk after the truce was declared and the devastation in the background has become an iconographic sign of helplessness that is bound to a exact location. Merely the caption indicates that she is in Beirut. This photograph from Lebanon follows certain image patterns that culturally learns to convey the picture of helplessness and that very often give us the situations in disaster and conflict zones in a similar form. Through their constant repetition, these pictures have become symbols to convey concrete testimonies of photography (Giannetti, 2008). 
The types of image, image patterns, have established the cultural memory by continual repetition and ultimately prove as part of the circular: Because they seem familiar, they must apparently correspond with reality and are accordingly believed. Certain contexts require time and again certain pictorial implementation patterns in this phase. Self- reference of press photography and visual language is being established in this context. The World Press Photo Award Competitions have a strong formative influence in this regard. Because of this, they set some image standards and role models. This process consciously or unconsciously affects the process images are involved in. Visualizations of suffering as in the example of the featured photographs are particularly common in iconographic image traditions and obviously show an emotional symbolism. In this context, I would like to briefly elaborate on Aby Warburg who created an Atlas of the collective image memory of a Mnemosyne project. In his Mnemosyne Atlas, Warburg gathered art and religion-historical imagery of two and a half millennia a compiled it on large panels. In his image Atlas, Warburg tried to group the images to image constellations and iconography series. He sorted the images according to various visual criteria; thereby he sought to disclose the connections between the different images. (Sladen, 1996) Like religion and art themselves, the Atlas is a collecting mirror of connective and mnemic energy. The Atlas is more than documentation, interpretation, and knowledge. In the collection of designs, in which affect energy and formal control are equally satisfied as constraint and order, Warburg used certain motifs and forms of representation of the cultural memory and called them pathos formulas, which symbolize emotional expressions with recourse to the ancient repertoire of forms in this cabinet of wonder. Warburg describes the rhetoric and semantic of body-related expressions as "historical psychology of human expression" and refers to the "interference between affect energy and cultural patterns of processing" coagulated to images and figures with the concept of pathos formula. Renewing pathos formulas, in the sense of aesthetic image quotations, which visualize an emotional expression, seems as a characteristic of press photography. Particularly emotions and emotional issues such as suffering and pain appear extremely ritualized in photojournalistic imagery. (Benjamin, 1973) The recourse to an iconographically familiar repertoire of forms and the return of emotional symbolism visualized this topics as easy-to-read symbols. This immediately recognizes the viewer as part of the cultural memory of the image. An example of this, the World Press Photo of 1997 (Visual 8) .

The so-called Madonna of Bentalha, a photograph of Hocine Zaourar from the Algerian civil war, shows a female figure sitting on the ground and compassionately held by another female figure. The expression of emotional mourning of the first female figure is evident. she has tilted her head to the side, her look is absent and the mouth open complaining. The headscarf wearing, weeping woman in the picture reminds of a form of presentation of Christian iconography, namely the Maria and the lamentation of Christ. Hocine's photograph taken after the massacre in Bentalha in Algeria on September 23, 1997, quotes the occidental Christian pictorial tradition and renews a pathos formula, which makes the figure an allegory of sorrow and pain. 
The iconographic reference to the lamentation of Christ brings the Algerian woman in motivic correspondence to Mary and the interpretation suggests that the Algerian woman mourns her children. So the recourse to the iconographic representation of patterns of mourning increases the symbol effect and immediately conveys the meaning (Sullivan, 2012).

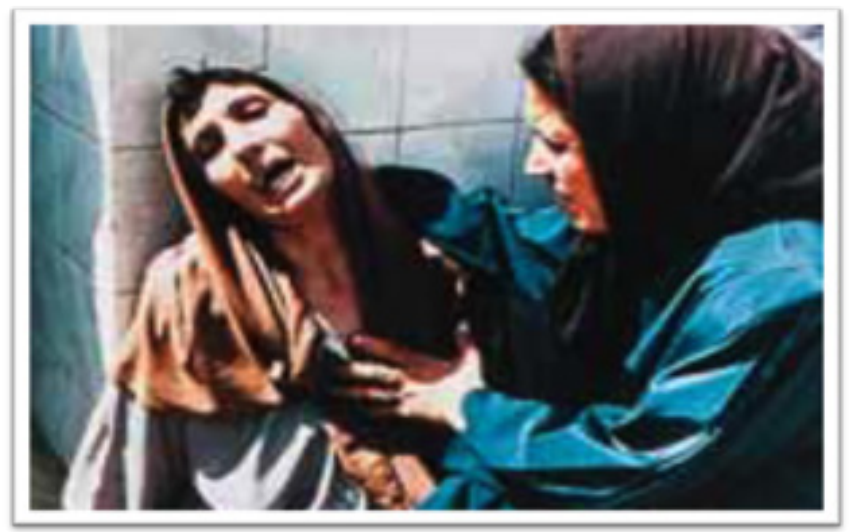

Visual 8. Hocine Zaourar/AFP: Bentalha, Algiers, Algeria, September 23, 1997, World Press Photo of the year 1997.

The specific modalities of perception, constituting themselves in the context of media, last but not least arise from the effects of a continuous flow of images that provides us round the clock with pictures of current events through different media channels. Within this constant image stream, we perceive images only in the context of other images, which necessarily leads to a trivialization and reduction of attention. The images are less read and decoded than merely scanned, i. e. covered in search of something striking or special.

This becomes especially clear when you consider the working conditions of most image editors, who investigate the mass of images they select through digital databases for the publications they work for. Here, image editors take your selection of search terms that enter into these databases. According to their input, they mostly get a variety of images of different providers that appear on their screens. For the journalistic image selection image editors make, the first step is therefore to get maximally $3 \times 4 \mathrm{~cm}$ small photographs depicted on the screen, in a later step to click to enlarge them, and then subject them to a closer scrutiny. It is clear that in the first step certain image-formal aspects and aesthetics, namely those relying on an easier readability of images in small format, are rather selected as, for example, images with a complex screen layout. Not least herein lies the reason why many pictures focus on shock effects since they offer the possibility to draw attention in the scanned image stream. In this respect, especially affective values of the images come to the fore. The preferred terrain of photojournalism is therefore the image affected with emotions. In this context, Susanne Holschbach speaks of a "style of the human". In the following, I assume this to be the typing of an imagery setting on emotions because 
Holschbach's term seems essential to the characteristic of many press photographs. It can be adapted to the emotionalization of a specific visual language, even if Holschbachs conceptualization of style to me ultimately refers to a purely stylistic component. The so-called "style of the human" often relies on the renewal of known pathos formulas (Sullivan, 2012).

Especially showing human feelings as sadness, joy, and pain seems the most immediate way to cause emotions of the viewer and to capture his attention. So, for example, the Stern, one of the largest German reportage magazines, formulated in a self-presentation of its philosophy it is looking to show "the human side of the news". The chief image editor Andreas Trampe said in an interview with the magazine Photonews that it is important for the Stern to print "tangible faces of history" and that the "Stern perspective" means "to show a person of a story in his or her authentic environment" (Giannetti, 2008 ). The Stern represents a kind of a 37-degree journalism deliberately seeking an emotionalization of images.

In the award-winning images of the World Press Photo Awards' Revue of the recent years, the importance and the dominance of the "style of the human" are visible, which made use of a familiar iconographic motif repertoire. For example, a color photograph of the French photographer Jean-Marc Bouju was selected to be the World Press Photo of the year 2003 (Visual 9). Bouju's image shows a detained Iraqis who comforts and protects his four-year-old son in a prisoner of war camp near the city of Najaf in Iraq. The image receives special drama by a bag which was placed over the father's head and by the composition of the image since the viewer sees the scene through a barbed wire barrier - an indication that the situation may not have been easily accessible for the photographers as witnesses.

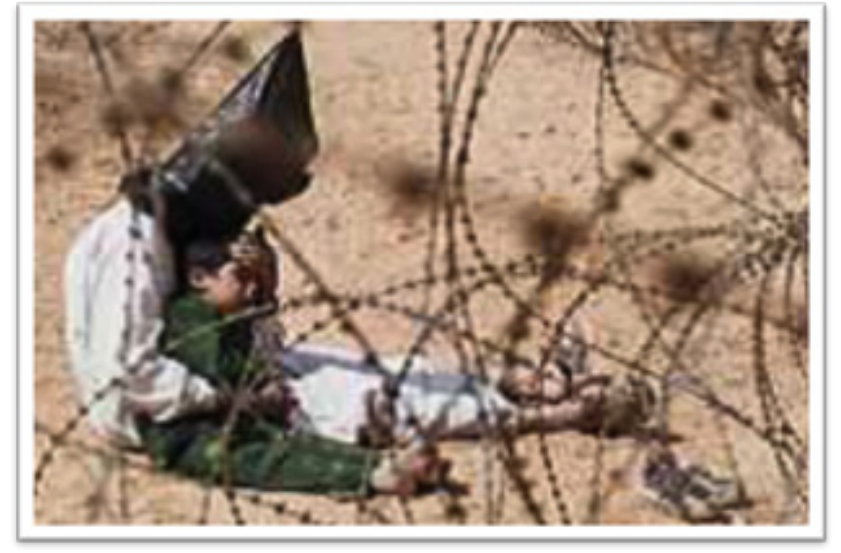

Visual 9. Jean-Marc Bouju/AP: on Najaf, Iraq, March 31, 2003, World Press Photo of the year 2003

The pathos formula of the gesture of the female figure is pointedly present in Chris SteelePerkins's photograph that recorded the massacre of 1,500 Palestinians on September 16, 1982 in the Sabra and Shatila refugee camp (Visual 10). In contrast to the iconography of Mary in quiet mourning, a dramatic gesture of despair is expressed. In the center of the image, a headscarfwearing woman spreading both arms far in a sweeping gesture can be seen. Her face is contorted 
with pain, the mouth wide open, the eyes half-closed. The shock and the sorrow as an emotional symbolism, which is further enhanced by evoking a synaesthetic perception, convey in this gesture of horror. The open mouth synaesthetically refers to the plaintive crying or screaming of mourners (Krautheimer, 1942). This works as in Edvard Munch's famous painting The Scream from 1893 (Visual 11), that immediately expresses the phenomenon of fear and despair about the horror of the gesture and brought the emotional symbolism into art history like hardly any other painting.

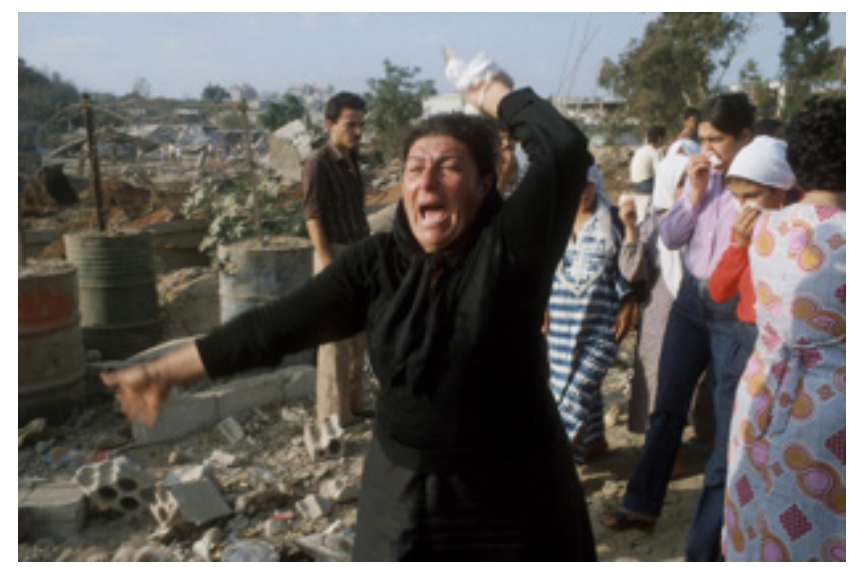

Visual 10. Chris Steele-Perkins: Sabra \& Shatila, Beirut, 1982

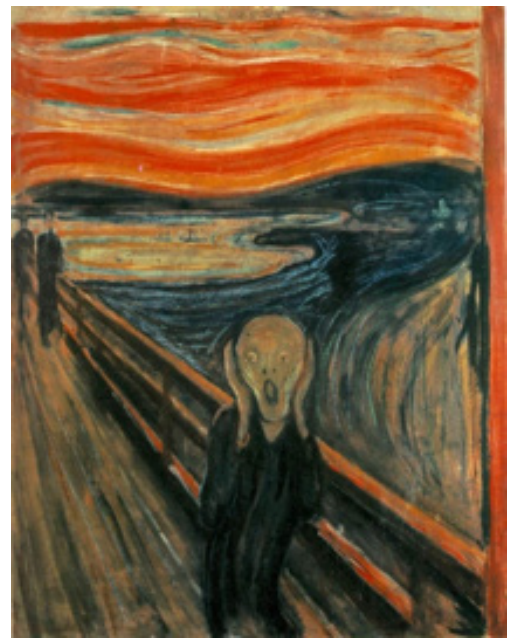

Visual 11. Edvard Munch's famous painting The Scream from 1893

\section{Photojournalistic Objectives}

A photojournalistic "style of the human" aims to prompt the viewer's emotions. In these shots, the degree of reality - the specific promise of reality - is measured less by objectivity and detachment of the photographs than by the mediation of authenticity, immediacy and emotion. Here, a way of distinction between documentary and authentic images opens up. It is the authentic of photographs allocated to the "style of the human" that evokes the impression of reality 
- not necessarily, but more often. Susanne Holschbach uses the term of "realness", which refers to the impression of an authentic image as to be close to the action (Cook \& Mieke, 1999).

The placement of authenticity in the sense of "realness" requires special image strategies. The criteria of the good image demanded by press photographs, which require technical precision, are often undermined given an authentic pictorial language. Basically, it can be stated that on the level of artistic implementation of the claim on readability its equivalent of journalistic photography in strong terms is on the technical perfection of recording. The original idea of technical precision to achieve the "good picture". Critical topos among the most image processes of media courses involved refers to categories. The figure of subjects and that of the essence of the statement in the center of the image as well as the requirement that content should be clearly identifiable and legible. The demand for a "good" press photograph requires compliance with certain formal criteria such as a straight horizon or the image and depth of focus. According to Sandra Abend, so-called "good" journalistic photos contribute to an event ever to be perceived. Nevertheless, the ideas of a "good" press photograph is subject to temporal changes and trends. In contrast to the claims of "good" pictures that can be found on the conveyance of "realness", press photography is often targeting just the opposite effect. It uses formal means such as motion blur, strong picture bleeds, and image motifs fading from the center of the image to express that the image was hard getting access to or could only be realized by chance. Also the position of the photographer as a witness of the seen, who tries to convey first-hand experiences, changes in the face of such image patterns, since the situation is always in danger to be changed by the presence of a witness. Therefore, the photographer as an observer must be rather invisible in these contexts. In the regard of photographing focused on immediacy and authenticity, images by amateurs or surveillance cameras get special meaning (Alunno, 2013).

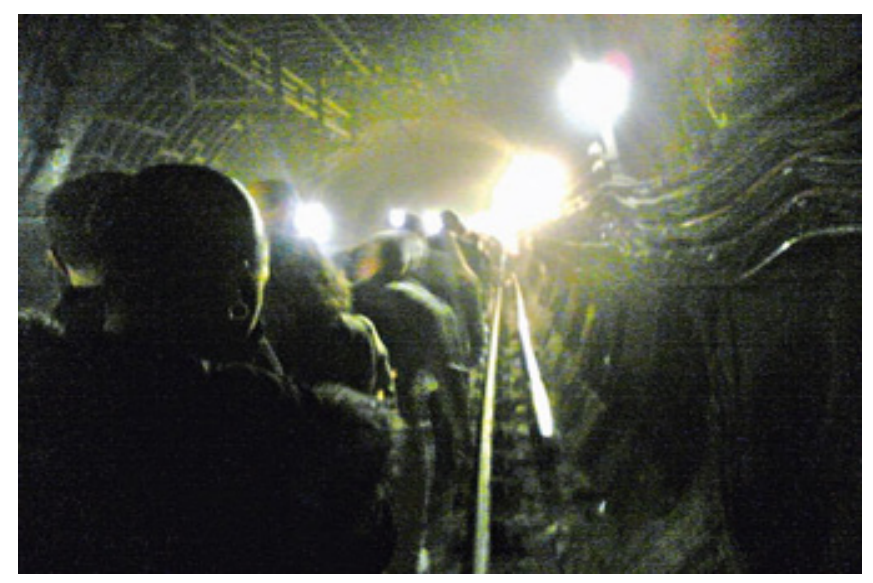

Visual 12. Alexander Chadwick: London, 2005. The subway passenger alexander chadwick photograph after the Bomb explosion near the Kings Cross Station with the mobile phone of a friend as passengers try to bring in safety. 
This is mainly due to the fact that oftentimes at the moment of an event no professional photographers are present, so that events such as the burning Concorde in Paris, the tsunami, or the terrorist attacks in London in 2005 were first photographed by lay people who had the possibilities to record them at the moment of their occurrence with mobile phones or digital cameras. Frequently, such images are picked up and distributed as press photographs by the media, as happened with the attacks in the London underground in 2005. The BBC obtained numerous photographs by photo amateurs and then put them on their news page (Visual 12) (Giannetti, 2008).

Meanwhile, the integration of such images or stills from amateur videos is very common and accepted. Also the pictures of the explosion of the reactor I in Fukushima in March 2011 went around the world as press photos and ultimately hark back to sequences of a surveillance video. Via the publication context, a documenting and proving function is attributed to these pictures, even if sometimes, as in the example of the explosion of the reactor at Fukushima, there is little to be recognized. The sequence of four individual images from the video shows a blurred view of the nuclear power plant. Three reactor blocks, one in the section on the right-hand side, and two of the cooling towers can be seen. The image sequence gives information about an apparently happening explosion indicated alone by the expanding clouds of smoke (Visual 13) (Alunno, 2013).

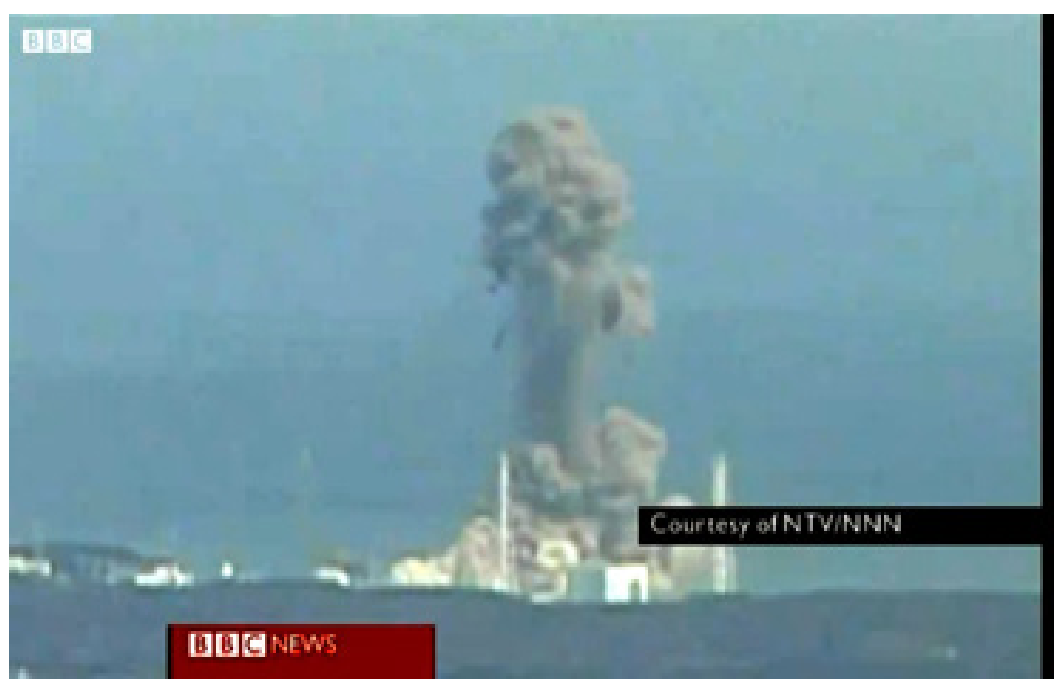

Visual 13.Explosion of the reactor Fukushima I, March 2011, (c) Reuters 


\section{CONCLUSION}

Ultimately, the perception of the image as an imitation of reality, as testimonies of history that connote both the references on history painting as well as on photojournalism in photography, revealed as rhetorical. That is because photography always, beyond every evoked reality promise, conveys starting points to decipher the conceived deception. The detection of deception is image-strategically achieved via grotesque figurative elements, which emphasize the artificiality of the representation and produce a break in the uniformity and the causality of the image narrative.

In this study, I took up the discourses on the relationship between photography and documentary to ask for the forms of reality policies and truth policies in the field of art. As my review of the recent literature about the relation between photography and documentary has shown, the relationship of photography, documentary, and art has only been reflected marginally and if so, then especially concerning the concept of artistic documentary photography. The existing literature can also hardly clarify the open and continuing fascination of the documentary and the question of how this fascination becomes important in photographic images located in an art context. In this respect, for me the question of the relation of art, photography, and documentary was central to encourage the discussion about the functions and features of a concept of the documentary. Why do many of the art works, in their reference to the documentary, relate just to the medium of photography? As my analyses of the artistic works show, these works full well draw on the power of suggestion and fascination of a photographic having recourse to the documentary.

Between the poles of the documentary, the art context, photography, and the event there is developing a perception of the events the pictorial worlds relate to and that does not aim at the documentation of the events. Instead, the works involve the viewers in an eventfulness of images by reflecting artistically that the event itself is actually not presentable, because it is always present and absent at the same time in the representation. With this, the artistic pictorial worlds do not suggest the documentation or the reconstruction of events, but bring home how these events only establish themselves via photos and in the process of viewing.

For just as the documentary is not to be understood as a result but as an action always linked with numerous power formations, the artistic images establish a relation to the events they have recourse to. However, they do not act as evidence that the events actually took place, but reflect that the readability of the world, the visual representation of events can never fully succeed. In this respect, the artistic approach is based on a difference to the event and is ultimately designed to loss. 


\section{REFERENCES}

Alunno, M, (2013), Iconography and Gesamtkunstwerk in Parsifal's Two Cinematic Settings in ESM Mediamusic. № 2. Medellin, Colombia

Bengamin, W, (1973), Charles Baudelaire: A Lyric Poet in the Era of High Capitalism, London.

Bengamin, W, (1989), Re the Theory of Knowledge, Theory of Progress ", in: Benjamin: Philosophy, Aesthetics, History, G. Smith (ed.), Chicago, pp 40-85.

Bialostocki, J, (2003), Iconography, Dictionary of The History of Ideas, Online version, University of Virginia Library, Gale Group. USA.

Cook, P \& Mike, B, (1999), The Cinema Book. 2nd ed. London: BFI Publishing.

Giannetti, L, (2008), Understanding Movies. Toronto: Person Prentice Hall, pp 523-527.

Krautheimer, R, (1942), Introduction to an "Iconography of Mediaeval Architecture", Journal of the Warburg and Courtauld Institutes, Vol. 5.

Okey, R, (2001), The Habsburg Monarchy, C. 1765-1918: From Enlightenment to Eclipse. European studies. Palgrave Macmillan.

Sladen, M, (1996), A Family Affair. Richard Billingham's Ray's A Laugh, in: Frieze 28.

Sullivan, B, (2012), The Real Thing: Photographer Luc Delahaye, in: http://www.artnet.com/magazine/ features/sullivan/ sullivan4-10-03.asp (access: 15. march, 2015).

Waskul, D, (2003), Self-Games and Body-Play Personhood in Online Chat and Cybersex, New York.

Wells, L, (2002), Photography: A Critical Introduction, London, New York.

\section{Figurs References}

Visual 1. Caspar David Friedrich: the Mer de Glace, 1823/1824http://www.efpfanfic.net $/$ viewstory.php?sid=2952299 (25.02.2016).

Visual 2. Firefighters raising the Flag at the WTC on September 11, 2001.

Photo by Ricky Flores Gannett News Service/The (Westchester, N.Y.) Journal News) http://www.100megsfree2.com/jjscherr/ scherr/091101.htm.

Visual 3. Anti-war: Mick Jagger took part in the demonstrations at Grosvenor Square, London in 1968 . Image ID: BTXR9X Copyright: (C) Daily Mail/Rex / Alamy Stock Photo. http://www.alamy.com/stock-photo-demonstrations-1968-jan-junanti-vietnam-war-protest-march-carrying-32551174.html (27.02.2016).

Visual 4. Egyptian anti-government protesters climb atop an Egyptian army armored personnel carrier, next to a signpost bearing the words "Down Mubarak", in Cairo, Egypt, Saturday, Jan. 29, 2011. (AP Photo/Ben Curtis) http://dailyme. tumblr.com/.

Visual 5. This first campaign is Action! for Diesel by KesselsKramer in Amsterdam. 2002. http://creativewondersblog.blogspot.com/2005_07_24_archive.html.

Visual 6. Terry Fincher. Starving children in Karamoja in northeastern Uganda during the famine of 1980. http://www. gettyimages.ae/detail/news-photo/starving-children-in-karamoja-in-northeastern-uganda-during-news-photo/79155914.

Visual 7. A woman looks at the destruction of Haret Hreyk after the ceasefire was declared on August 15th, 2006. (02006 Derek Henry Flood. http://the-war-diaries.com/?p=756.

Visual 8. Hocine/AFP: Bentalha, Algeria, Algiers, September 23, 1997, World Press Photo of the year 1997, in: World Press Photo 98, hg. Foundation World Press Photo, http://karynavso.blogspot.com/.

Visual 9. Jean-Marc Bouju/AP: Najaf, Iraq, March 31, 2003, World Press Photo of the year 2003, http://karynavso.blogspot. com/.

Visual 10. https://en.wikipedia.org/wiki/The_Scream\#/media/File:The_Scream.jpg 2015. 
Visual 11. Chris Steele-Perkins: Sabra \& Shatila, Beirut, 1982, Magnum Photos/agency focus. http://www.magnumphotos. com/C.asp $x$ ?VP3=SearchResulte $A L I D=2 T Y R Y D H Z N V E H$.

Visual 12. alexander chadwick: london, 2005. htpp://blogs.smh.com.au/photographer/archives/2007/07/.

Visual 13. explosion of reactor Fukushima 2011, http://humansarefree.com/2014/01/there-was-nuclear-explosion-at.html 
